\title{
Drug company 'suppressed' publication of research
}

been reached. Any such agreement would need to be signed by Euratom, which is responsible for enforcing safeguards on all civil nuclear materials within Europe.

Similarly, Leventhal describes the proposed deal between France and Russia as evidence that France feels immune from international norms on nuclear nonproliferation. "It's just a further attempt by the French to stick a thumb in the eye of the US in the nonproliferation field," he claims.

The United States has applied strong diplomatic pressure to Euratom and Russia to prevent them from opening up trade in HEU. Indeed, some US congressmen had pressed for the United States to block renewal of the US-Euratom agreement which covers trade in nuclear materials until Europe and Russia agree not to trade in HEU (see Nature 379, 760; 1996).

While such diplomatic pressure is continuing, the signing of the US-Euratom agreement itself represents a setback for US efforts. The agreement contains a letter from Stuart Eisenstat, the US ambassador to Euratom, which states that the United States is "committed to eliminating [the civil use of HEU] over time".

But the letter also states that the United States recognizes "that specific research reactors in the European Atomic Energy Community may, under certain circumstances, need to use highly-enriched uranium as fuel". This loophole is reported to have been included after intense European pressure.

Costas Verros, a spokesman for Euratom, says that the letter is explicit recognition that several European reactors cannot convert to LEU at present. "The matter is settled," says Verros, adding that Euratom has "an obligation to help operators to find the fuel they need". Verros points out that the European Union has signed an agreement with Russia similar to that between Euratom and the United States on the peaceful uses of nuclear technology, and that this allows European countries to seek HEU in Russia.

Declan Butler
Washington. Controversy over the secrecy demanded of biomedical researchers by pharmaceutical companies captured the limelight again last week, with a report that a company had suppressed the publication of a journal article out of fear that the conclusions would hurt the multi-million dollar sales of one of its products, a thyroid drug.

The story, first reported in The Wall Street Journal, tells how the British company Boots Co. apparently succeeded in persuading Betty Dong, a researcher it had funded at the University of California, San Francisco (UCSF), to withdraw a paper scheduled to appear in the Journal of the American Medical Association (JAMA).

Soon after the article was due to have appeared in January 1995, Boots' drug division was bought by Germany's BASF AG, for $\$ 1.4$ billion. Synthroid, a drug made by the division which is used in hypothyroidism, and which accounts for 84 per cent of the $\$ 600$-million US market for thyroid replacement drugs, is thought to have figured prominently in the price paid.

Boots' huge share of the market reflects the inability of its rivals to prove beyond doubt that their products were 'bioequivalent' to Synthroid. In the 1980s, Boots' drug division - now part of Knoll Pharmaceutical Co., a New Jersey division of BASF decided to prove its rivals' inferiority for good. The company sought out Dong, a clinical pharmacist, and paid her $\$ 250,000$ to carry out a comparative study of Synthroid and three alternative drugs.

But the results were not what Boots expected. Dong and her research team found that the alternatives were 'bioequivalent' - that they were absorbed in the blood in the same way as Synthroid - and that use of the significantly cheaper, equally effective

\section{Austrian academics fight teaching fee review}

Munich. The Austrian research minister, Rudolf Scholten, has invited university academics and students, who have been on strike since Easter, to suggest how the country should save ÖS1 billion (US\$94 million) from the university budget over the next two years.

Scholten's own proposals for making the large savings dictated by Austria's financial crisis had been greeted with horror by students, who could lose privileges such as free public transport, and by academic staff, particularly the socalled Mittelbau, equivalent to assistant and associate professors, who could lose a large proportion of the generous teaching fees on which they rely

\section{because most are employed by universi-} ties only part-time.

Scholten wants to save nearly half of his ÖS1 billion target by paying low fees - or no fees at all - to those who give a few lectures a term, and then pay progressively higher fees for more teaching hours. This is opposed by groups such as the Federal Conference for Scientific Staff, which argues that this system would encourage young academics to neglect research in favour of doing more teaching to maintain their income.

But Scholten argues that the quality of Austrian research has already suffered from the current system of piecework. alternatives would reduce US health-care costs by $\$ 356$ million a year.

After several years spent trying to discredit Dong's findings - including hiring private investigators to search her background for conflicts of interest - Boots succeeded in blocking publication, using the fact (which neither side denies) that when Dong began the work, she signed a contract promising the results would not be published "without written consent" of the company. The company allegedly threatened Dong and her colleagues with a lawsuit if she published - an allegation that a Boots executive adamantly denies.

Faced with the prospect of ruinous legal fees, as well as a reversal by UCSF, which initially backed her efforts to publish, but then said it could not because of the legal risk, Dong told $J A M A$ to cancel her paper, which was already at the printer. She has not succeeded in finding another publisher.

Meanwhile, Gilbert Mayor, formerly director of medical services for Boots and now the senior director of medical research at Knoll, was the lead author on a lengthy critique of her unpublished findings in the American Journal of Therapeutics, of which Mayor is an editor, in June 1995.

Carter Ekert, the Boots executive who instigated Dong's study, told The Wall Street Journal: "I stopped a flawed study that would have put millions of patients at risk." Notwithstanding its acceptance by JAMA peer reviewers, the company has argued that the study contained mistakes in data analysis and patient management, among other things, due to factors which the reviewers would not have been aware of.

UCSF officials say that the study is "valid" and without "significant" flaws. They add that Dong violated university policy by signing the contract, calling its limitation on her right to publish "not acceptable".

The university also defends its decision not to make its legal resources available to Dong and her colleagues. In its statement, it calls the right to publish "the essence of what a research institution is all about". But, it continues, "the difficulty here is weighing the right to publish against a likely claim against the University for breach of contract and the possibility of significant damages".

Dong told The Wall Street Journal that signing the contract was naïve, that she ought not to have signed, and that she will not do drug company-sponsored research again. Stephen Rosenberg, the chief of surgery at the National Cancer Institute in Bethesda, Maryland, and a strong critic of biomedical secrecy, says of the episode: "I'm shocked. But I'm not surprised." 